\title{
STEAM CONSUMPTION IN AN ELECTRIFIED SUGAR MULL
}

By José R. Carreras, B.S., Chief Engineer, Juncos Central Co.

This paper is a brief abstract of a complete study made on the steam consumption of a sugar factory of this Island, with a quadruple efiect evaporative installation, and on the expected steam consumption after the addition of a pre-evaporator which would supply also rapors to the juice heaters.

The scheme of adding a pre-evaporator to a quadruple effect forming a quintuple, and at the same time, supplying vapors at double effect to the juice heaters, is not new, as most of you may know. Noel Deerr in "Sugar" and Hausbrand in "Evaporating, Condensing, and Cooling Apparatus", treat that and similar schemes fully, and actual installations may be found in Cuba, Hawaii and other countries. So far as I know, though, this system has never been worked before in Porto Rico.

Before going into the discussion of the steam requirements, in the actual and in the system in project, a brief description of the fectory apparatus and process is necessary.

Actually, the factory is almost wholly electrified. It has one $750 \mathrm{KW}$. Westinghouse Reaction type steam turbine and one 500 IW. Westinghouse Impulse type turbine. One Corliss engine of $120 \mathrm{HP}$. and one Corliss engine of $450 \mathrm{HP}$. drive most of the mill, and $100 \mathrm{HP}$. in small steam pumps are scattered in various works in the factory.

The juice is passed through three juice heaters, 1,250 square feet H. S. and heated to 212 degrees Fahr. After being clarified, it caters the quadruple effect at an average temperature of 180 clegrees Fahr., and leaves as syrup of 27 degrees Beaume. Strikes of "Puras" and "first", massecuites are done in a calandria pan; "second", "third" and some "first" are done in two-coil paus.

The juice heaters and quadruple effect work with exhaust steam and the addition of live steam to mantain $6 \mathrm{lbs}$. ga. back pressure at the evaporator, or $11 \mathrm{lbs}$. ga. at the engines.

The calandria pan works with exhaust steam exclusively. The coil pans work mainly with live steam. 
With the system in project, the juice heaters will work with vapors from the pre-evaporator; the pre-evaporator will work with the exhaust steam pressure same as previously; the calandria pan with exhanst exclusively, and the coil pans with live steam mainly, or if able, with exhaust steam exclusively. A new juice heater, 1,000 square feet H. S. will be installed also, for reheating the juice after clarification, and will work with vapors from the pre-evaporator.

Now, a word before submitting the results obtained. It would be foolish to claim exactness in the figures to be submitted. They represent the results from average conditions at the usual heavy rate of grinding and for maximum normal extraction of 83 per cent and 35 per cent dilution on cane. The calculations have been made mainly to show the relative proportions among the steam requirements of the different apparatus in the old and in the system in project. Please remember, therefore, that the tabulation of results given below must be considered as fairly approximate to the steam consumption of the apparatus.

TABUTATION OF RESULTS FOR THE $750 \mathrm{KW}$. TURBINE UNIT IN SERVICE

\begin{tabular}{|c|c|c|c|c|c|c|}
\hline & 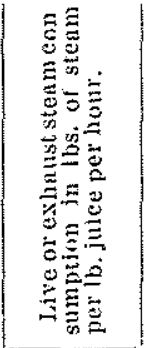 & 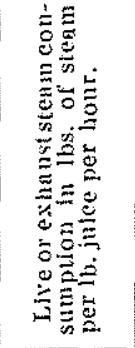 & 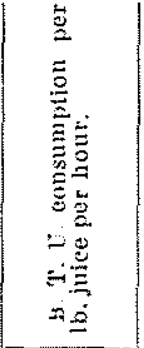 & 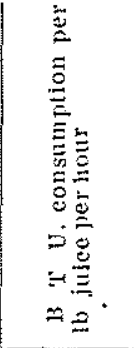 & 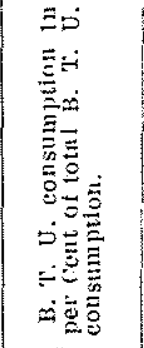 & 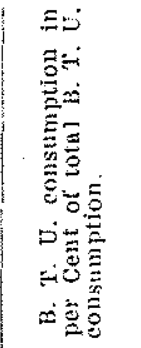 \\
\hline & Quadruple & Quintuple & Qundruple & Quintuple & Quadruple & Quintungas \\
\hline 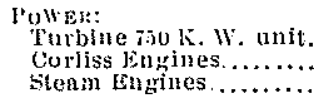 & $\begin{array}{l}0.2491 \\
0.1054 \\
0.0616\end{array}$ & $\begin{array}{l}0.2491 \\
0.1051 \\
0.0616\end{array}$ & $\begin{array}{r}25.21 \\
10.19 \\
1.57\end{array}$ & $\begin{array}{r}25.24 \\
10.19 \\
1.57\end{array}$ & $\begin{array}{l}4.97 \\
2.01 \\
0.81\end{array}$ & $\begin{array}{l}6.01 \\
? .43 \\
0.47\end{array}$ \\
\hline 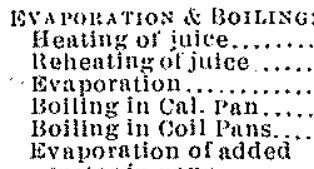 & $\begin{array}{l}0.1350 \\
0.0494 \\
0.22 \% 0 \\
0.0931 \\
0.0068\end{array}$ & $\begin{array}{l}0.00519 \\
0.3135 \\
0.0809 \\
0.0068\end{array}$ & $\begin{array}{r}118.80 \\
10.14 \\
192.44 \\
80.66 \\
6.51\end{array}$ & $\begin{array}{r}1.50 \\
270.47 \\
70.04 \\
6.54\end{array}$ & $\begin{array}{r}33.35 \\
7.88 \\
37.98 \\
15.85 \\
1.29\end{array}$ & $\begin{array}{r}1.07 \\
64.51 \\
16.71 \\
1.56\end{array}$ \\
\hline water in pans.......... & 0.0212 & 0.0212 & 20.42 & 20.42 & 4.02 & 4.87 \\
\hline $\begin{array}{l}\text { Lostes: } \\
\text { Stenum pipe losses........ } \\
\text { Condensation losses.... }\end{array}$ & $\begin{array}{l}0.0020 \\
0.0105\end{array}$ & $\begin{array}{l}0.0020 \\
0.0087\end{array}$ & $\begin{array}{r}2.00 \\
10.05 \\
\end{array}$ & $\begin{array}{l}2.00 \\
8.40 \\
\end{array}$ & $\begin{array}{l}0.39 \\
1.98 \\
\end{array}$ & $\begin{array}{r}0.17 \\
2.00 \\
\end{array}$ \\
\hline & & & 508.05 & 419.37 & 100.00 & 100.00 \\
\hline
\end{tabular}




\section{Comparative Heat Balance in Pounds Steam per Pound Juice per Hour, $750 \mathrm{KW}$. Turbine Unit in Service}

\section{WITHOE! PRE-EVAPORATOR SXSTEM:}

Fihaust produced by-
Turbine
Corliss engines
Steam engines 0.0616

Fxhaust required-

Wirst heating 0. 1370

Reheating-

0.0464

Fraporation

0.2230

Boiling in enlandria 0.0931

Deficit in exhaust steam - -

0.0834

$0.4995 \quad 0.4995$

Defieit in exhaust steam_...-

Defieit in live steam equiralent.

0.0834

0.0746

Using PR'-Evapchaton System:

Exhatust produced by-

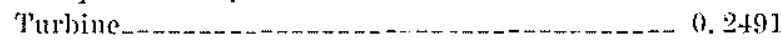

Corliss engines ............... 0.1054

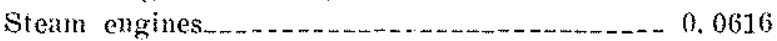

Exhanst required-

First heating _._.

Reheating -

Wraporation _............ 0.0052

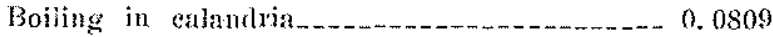

$\begin{array}{ll}- & 0.3906\end{array}$

Excess in exhaust stetm_...

0.4161
0.4161

Excess in exhatust steam _........................... 0.0165 


\section{TABULATION OF RESULTS FOR THE $500 \mathrm{KW}$. TURBINE UNIT IN SERVICE}

\begin{tabular}{|c|c|c|c|c|c|c|}
\hline . & 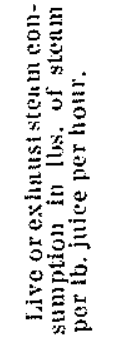 & 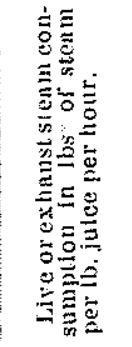 & 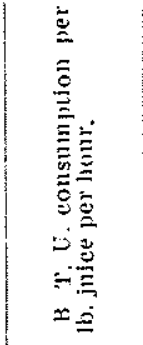 & 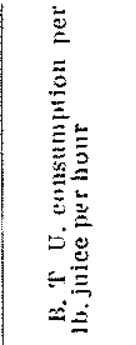 & 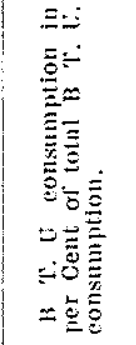 & 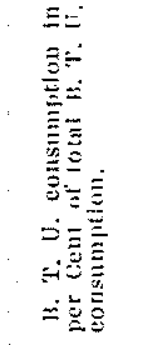 \\
\hline & & Quintuple & Quadruple & Quistuple & Quadruple & Quintuple \\
\hline 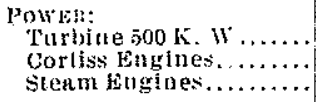 & $\begin{array}{l}0.1814 \\
0.1054 \\
0.0616\end{array}$ & $\begin{array}{l}0.1819 \\
0.1054 \\
0.0616\end{array}$ & $\begin{array}{l}38.74 \\
10.13 \\
1.57\end{array}$ & $\begin{aligned} 18.74 \\
10.19 \\
1.57\end{aligned}$ & $\begin{array}{l}3.73 \\
0.03 \\
0.31\end{array}$ & $\begin{array}{l}1.56 \\
0.419 \\
0.37\end{array}$ \\
\hline 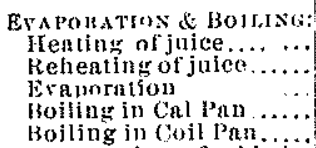 & $\begin{array}{l}0.1370 \\
0.0464 \\
0.2230 \\
0.0931 \\
0.0058\end{array}$ & $\begin{array}{l}0.0052 \\
0.3135 \\
0.0809 \\
0.0068\end{array}$ & $\begin{array}{r}118.80 \\
40.14 \\
19.2 .41 \\
80.66 \\
6.54\end{array}$ & $\begin{array}{r}1.50 \\
270.47 \\
70.04 \\
6.54\end{array}$ & $\begin{array}{r}23.67 \\
8.01 \\
38.57 \\
16.010 \\
1.30\end{array}$ & $\begin{array}{r}1.118 \\
6.53 \\
16.96 \\
1.58\end{array}$ \\
\hline $\begin{array}{l}\text { Preparation oî added } \\
\text { water jn Pan } \ldots . . . \cdots\end{array}$ & 0.0212 & 0.0212 & 20.42 & 20.42 & 4.07 & 4.45 \\
\hline 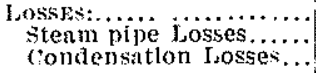 & $\begin{array}{l}0.0020 \\
0.0105\end{array}$ & $\begin{array}{l}0.0020 \\
0.0087\end{array}$ & $\begin{array}{r}2.0 ! \\
10.03\end{array}$ & $\begin{array}{l}5.00 \\
8.50\end{array}$ & $\begin{array}{l}0.111 \\
2.00 \\
\end{array}$ & $\begin{array}{l}0.48 \\
2.08\end{array}$ \\
\hline & & & 501.55 & .112 .87 & 100.00 & 100.00 \\
\hline
\end{tabular}

\section{Comparative Heat Balance in Pounds Steam per Pound Juice per Hour, $500 \mathrm{KW}$. Turbine Unit in Servịce}

WITHOU: I'RP-HVAPCRATOR SYSTEM:

Exhaust produeed by-

Turbine

Corliss engines

Steam engines 0.0616

Exhaust recpuired-

First heating.

Reheating

Evaporation

0. 2230

Boiling in ealandria 0.0931 
Using Pre-evaporator System:

Exhaust produced by-

Turbine

0.1849

Corliss engines

0.1054

Steam engines.

0.0616

Exhaust required-...

First heating - 0.000

Reheating

Evaporation____._. 0.3135

Boiling in calandria _._._......... 0.0809

0.3519

Deficit in exhaust steam

0.0477

0.3996

$0.3996 \quad 0.3996$

Deficit in exhaust steam

Now, let us discuss the figures obtained for the $750 \mathrm{KW}$. turbine unit, which is our most convenient condition in the actual installation.

Without the pre-evaporator, 0.0746 pound of live steam per pound juice per hour must be added to the exhaust for the heating requirements. If we could save this live steam, the economy for a 24-hour day would amount to-

$162,250 \times 0.0746 \times 24 \div 7.37=39,415$ pounds of coal, or 17.6 netric tous per day.

Coal is considered as having 11,850 B.T.U.

Efficiency of boilers as 60 per cent.

Equivalent Evaporation $=11,850 \times .6 \div 963.61=7.37$.

If a $\$ 10$ price per metric ton of coal is considered, and if it were posible to maintain the 1,500 tons per day rate of grinding during 125 days of the season, the saving would amount to-

$17.6 \times 10 \times 125=\$ 22,000$ for the year.

With the installation of the pre-evaporator under the scheme explained, it is seen from the tabulations, that working with the $750 \mathrm{KW}$. turbine unit, there will not be the necessity to add any live steam to the exhaust; to the contrary, there will be an excess of exhaust steam of 0.0165 pound per pound juice per hour, which represents about $0.0165 \times 100 \div 0.4161=4$ per cent of the total exhaust steam produced. This excess may be employed to substitute live steam in the coil pans, and thus its loss be avoided.

For the $500 \mathrm{KW}$. unit, the difference between the deficit of exhaust steam in both cases is $0.1476-0.0477=0.0099$ pound cxhaust per pound juice, or 0.0894 pound equivalent live steam 
Fer pound juice per hour, in favor of the projected system. This is a saving of 21.08 metric tons coal per day, or $\$ 26,350$ per 125 days grinding.

With this turbine in service, there will always be required a small amount of live steam for the normal evaporating load, and there will rarely be occasions of excess exhaust. We expect that it will prove to be the most economic scheme for the factory.

Since a pre-evaporator installed under the discussed system, compietely erected with its accessories, will cost about $\$ 25,000$, it is our opinion that it is a worthwhile investment to be made in any sugar factory. Its cost may be saved almost completely in just a year of grinding.

A paragraph of explanation before I close. The amount in dollars that we claim may be saved in a year of grinding, we don't mean it to be necessarily in dollars. The saving made will appear in the value of the coal economized during the year and in the value as a fuel of the bagasse pile left over as excess.

To those interested in this matter, the tabulations of results given in this paper may be helpful in some other considerations that come along with the problem, but that I do not deem proper to discuss now. Our aim has been merely now to call your attention to the distribution of the steam load in the factory and to the large saving that may be made in fuel consumption, if schemes are worked toward the diminution of the steam consumption in the evaporating and graining stations of the factory. 